\title{
Service Quality Determinants in Highway Travel Services: A Research on Y-Generation
}

\author{
Asst. Prof. Dr. İlkeBaşarangil ${ }^{1}$,Nalan Nişikli ${ }^{2}$ \\ ${ }^{I}$ Kırklareli University, Tourism Faculty, Department of Travel Management and Tourism Guidance, Kırklareli, \\ TURKEY \\ ${ }^{2}$ Kirklareli University, Institute of Social Sciences, The Department of Tourism Management, Graduate Student, \\ Kırklareli /TURKEY
}

\begin{abstract}
Y-generation as Millennium consumers with different expectations should be informed about the points of interest and wishes of their travels and services should be provided according to their needs. Therefore, efforts have been made to reveal the travel service quality determinants of Y-generation and to reveal and review these determinants in terms of demographic variables. For this purpose, a questionnaire was applied to the 425 tourism students of Y-generation studying at Kirklareli University Faculty of Tourism. SPSS 22.0 was used for analysis of the obtained data. In the analysis of the data, descriptive statistics, Factor Analysis, T-Test and ANOVA analyzes were used. The travel service quality determinants of the Y-generation have been revealed as "Attitude and Behavior of the Personnel", "Physical Qualities of the Bus", "Technology Usage", "Ticket Sale Transactions and Punctuality", "Supporting Services", "Facilitating Services" and "Stopovers". Suggestions had been developed for destination management organizations and the travel agencies.
\end{abstract}

Keywords: Y-generation, Service Quality Determinants, Satisfaction, Travel, Tourism.

\section{Introduction}

People can use travel agencies and tour operators to make their travels, as well as supporting enterprises such as rent-a-cars, transporting businesses, enterprises providing travel insurance, etc. (Zengin\&Şen, 2015: 53-54). In the 1960s, 1970s and 1980s, large-scale service providers such as financial services, insurance, retail, transportation, accommodation, catering experienced extensive growth (Middleton et al., 2009: 40). The tourism movements that started with trains in the world have gained momentum with the development of cars and buses. The touristic trip by bus took place in England in 1910, then in Paris in 1918. The fact that railways are not sufficient in our country and air travel is partly expensive played a major role in the development of bus transportation (İçöz, 2000: 16). According to the statistics of the Turkish Statistical Institute in 2015, the number of passengers carried by roadway has exceeded 290 million (http://www.tuik.gov.tr). In parallel with the increase in the number of passengers, the number of bus companies also increased and the number of buses carrying intercity passengers reached 31,935 and the number of buses reached 52,707 (www.ubak.gov.tr) in 2011 according to the Ministry of Transportation. Intercity passenger transportation is among the important sectors of our country with 350.000 employees and an annual added value of 3 billion dollars (Ardıç\&Sadaklıoğlu, 2009: 167). Generally, the preference rate of highways, which have an important place in domestic tourism and tourist movements in Turkey, is 96\% (Kozak et al., 2014: 48).

The younger generations nowadays reasonably spend a portion of their time in transportation vehicles with reasons such as work, education, tourism, discover new places, visits to friends and relatives, etc. and in the meantime, they want to receive comfortable, smooth and best service. In order to keep up with this competition, bus operators apply various ways (physical structure of the bus, comfort, etc.). All of these efforts are aimed at satisfying the needs of the customers in the best way. As far as it is important for customers, customer satisfaction is an important indicator for increasing the income and prestige of the bus transportation enterprises, since satisfied customers will be able to choose the same business or even propose them to their immediate surroundings. Based on these reasons, this research aims to reveal the service quality determinants of Y-generation university students in their road trips and to examine these determinants in terms of demographic variables.

\subsection{Y-generation and travel perceptions}

\section{Literature Review}

The generations are classified in the social history process as (1) the Silent Generation, born between 1922-1945; (2) the Baby Boomers, born between 1946-1964; (3) Generation X, born between 1965-1980; (4) Y-generation (Echo Moomer/Millennials), born between 1981-2000; (5) Z generation, Crystal kids, 2001-2020. The Millennium (Y-generation) youth, representing today's youth, is the first generation of information society 
and postmodern culture. The Millennium generation is both fond of individuality and freedom and committed to their families. They are part of the consumer society at the same time both experiencing global culture and local culture (Bayhan, 2014: 8; Altuntuğ, 2012: 205-207). According to Lower (2008), the range of birth years of this generation is not limited by any parameters. According to most experts, this generation is used for those born between 1980 and 2001. They are named with different names such as Millennials, Generation Next, Digital Generation, Echo Boomers and Nexters (Adigüzel et al., 2014: 173). Y-generation also brings many new technologies, social networks, a technology-savvy culture, new business practices and management styles. The members of this generation bring energy and innovation to their workplaces and require good management accordingly (Yüksekbilgili, 2013: 344). Among the qualities of Y-generation are the fact that they do not like the hierarchical structure, they are demanding, they are impatient because they have never experienced poverty, and their spirit of entrepreneurship is very prominent (Latif \&Serbest, 2014: 156). In working environments, Ygeneration employees have a higher average value in the dimensions of multitasking, social media usage, tendency for team work and working while having fun, while they have low average value in the dimension of organizational loyalty (Çemberci et al., 2014: 70-71).

Researches on the travel perceptions of the Y-generation are included in the literature. Seçilmiş\&Köz (2015: 75), who study the effects of sustainable culture tourism perception on the intention to revisit, suggest that services should be provided so that their interests and wishes can be determined at what points they change and respond to their needs. For example, the satisfaction level of Y-generation members seems to be low. They note that, therefore, the Y-generation's slightest dissatisfaction will affect their repeat visits negatively and that it is important to remember that they will also play an active role in the preferences of potential visitors via social media because of their dedication to technology. Albayrak\&Özkul (2013) have concluded on their research on the destination image perceptions of Y-generation tourists survey of destination image perceptions that these generations are composed of individuals seeking rest, enjoyment and new places, seeking quality and luxurious vacation favors.

TripBarometer, introduced by TripAdvisor in 2012, is designed to measure and track the trends in the global travel industry between business owners and consumers. Ipsos MORI has been conducting this survey since 2014 and 2016 is the 6th section. It includes 34.026 participants, broken down into the millennium generation $(22 \%)$, X-generation $(65 \%)$ and those born after the World War II (13\%). Millennium consumers did not have enough money for travel and $30 \%$ want to visit cheaper countries. Eight percent of the millennium consumers make reservation via mobile applications. Online content and media content are very influential to the Millennium Climate, and they also have a passionate and adventurous spirit that goes to destinations for a variety of options, from adventure travel to getaways to spiritual experiences. The perceptions of the Ygeneration (Millennium generation) are as follows;

- Ambitious, adventurous and open to new ideas for his travels,

- For this generation, positive feedbacks and good-priced flights are more important,

- They heed the suggestions of their families and friends while planning trips,

- Movies and TV shows are quite important for this generation to choose a destination,

- While the air conditioner in the room is very important for other generation, Wi-Fi and the breakfast being included in the room price is very important for Millennium generation,

- This generation wants water heater, very fast Wi-Fi connection, room service etc.,

- Most of the millennium generation looks for adventure (82\%), $28 \%$ of them plan an adventurous vacation for the next year,

- Millennium generation mostly (87\%) takes their smart phones while going on a trip as well as their private event/night dresses (49\%),

- While travelling, their own towels (33\%) are among the most important personal commodities that they carry (https://d2bxpc4ajzxry0.cloudfront.net/TripAdvisorInsights).

Y-generation makes travel reservations from the internet according compared to older generations. Ygeneration has a different vacation activity profile. These generations are more inclined to visit friends, shop, eat at restaurants, go to disco, night life and beach vacations. On longer travels, they prefer different destinations. While America, Asia, Australia and Europe are strong preferences, New Zealand is among the weaker preferences (Kattiyapornpong, 2009: 3). Y-generation goes on vacation once or twice a year, spending an average of 7 days on vacation; $74 \%$ of them go to overseas trips; the majority of participants (71.8\%) do not want to travel to developing countries and researching travel destinations is very important by $42 \%$. They generally do not conduct this research through a single information source, benefiting from information sources such as TripAdvisor and Lonely Planet, Rough Guide and DK, Frommer's and Fodor's instead (Franzidis\&Hritz, 2014: 329). 


\subsection{Servicequality determinants in travel}

The quality is related to the characteristics and standards of service (Horner \&Swarbrooke, 2005: 396). Servicesare classified as transportation, accommodation, reception, catering and other services (repair, maintenance, medical service, currency exchange, etc.) (Godfrey \&Clarke, 2000: 71). The perceived quality of service is the difference between the perceptions and expectations of the customers. SERVQUAL scale has been developed to measure service quality (Parasuraman et al., 1988: 17, Parasuraman, et al., 1994: 207). Grönroos (1984) described "technical quality", "functional quality" and "organizational image" as service quality determinants. When service quality exceeds customer expectations and customer satisfaction is achieved while customer dissatisfaction occurs below the perceived service quality expectations (Öztürk, 2010: 151). Outstanding service leads to customer satisfaction. Customer satisfaction and loyalty are very important concepts in terms of people visiting the enterprises again and of long-term profitability (Goeldner\& Ritchie, 2012: 423). Brady and Cronin (2001) listed the factors contributing to the service quality as "interaction quality (attitude, behaviour, expertise)", "physical environment quality (ambient, design, social factor)" and "outcome quality (waiting time, tangibles, valence). Research on the effect of customer experience on perceived service quality or perceived value is included in the literature (Urban, 2010; Chen \& Chen, 2010; Gurski, 2014, Wu et al., 2015).

Research studies on the service quality in passenger transportation of travel enterprises are included in the literature. Ardıç\&Sadaklığlu (2009) have developed 7 different components in the research on service quality in intercity passenger transportation as service quality determinants; being attitude and behavior of the personnel, physical qualities of the buses, punctuality, accommodation and stopovers, reservation, service and baggage enterprises and office operations. According to Özgüven (2008: 677), on the other hand, personal accident insurance is the first choice among customers to choose a bus company operating in the travel industry followed by price, service quality, safe and comfortable vehicle, compliance to speed limit and traffic rules and finally, good-humored service. Meanwhile, Altan\&Engin (2004) ranked the captain first in the rank order of importance of the factors affecting the general evaluation of travel, catering and service ranked second, booking and ticket sales ranked third, respect to the guest ranked fourth, hospitality ranked fifth, host-hostess ranked sixth and hygiene was ranked seventh. Duman et al. (2007), stated the services dimensions in highway passenger transportation as office-service-terminal services, travel services and stopover services. Customer loyalty determinants have been found to be travel services and office-service-terminal services. Y1lmaz (2012), on the other hand, named the service quality perceptions of university students regarding the services provided by long distance bus companies as "issues related to office, office staff and bus personnel", "issues related to buses and services provided during travel", "safety-related issues", "stopover-related issues" and "issues relating to reservation, ticket purchases and baggage". The perceptions of the students on the six factors (service quality) were found to be low. Koçoğlu\&Aksoy (2012) found in their research on the service quality in business enterprises that the service quality determinants were kindness, physical elements, reliability, enthusiasm and competence. While determining the relationship between customers' ages and satisfaction, no relationship have been between gender, educational status, income status and satisfaction.

\subsection{The Purpose, importance and hypotheses of the research}

\section{Research methodology}

Y-generation youth in our country travels with purposes such as education, tourism, participation, visit to friends/relatives, etc. Knowing what the factors creating satisfaction in the highway travels of a generation, which is fond of freedom, conscious, technology-savvy, and that particularly enjoys recreational experiences, is important in terms of travel enterprises. Positive developments in passenger satisfaction can be achieved by knowing the satisfaction factors that affect Y-generation. Thus, with economic improvements, enterprises can increase their profitability. Companies that want to create a competitive advantage in highway transport can make a difference to their competitors if they can correctly understand the expectations of Y-generation youth in terms of service quality. When all these elements are taken into consideration, efforts have been made to examine the factors that will cause satisfaction on the travels of Y-generation are revealed and whether these elements are different in terms of demographic variables. The hypotheses developed within the scope of the research in terms of theoretical structure are as follows;

$\mathbf{H}_{1}$ : There is a statistically significant difference between the gender variable of Y-generation and the service quality determinants they perceive.

$\mathbf{H}_{2}$ : There is a statistically significant difference between the age variable of Y-generation and the service quality determinants they perceive.

$\mathbf{H}_{3}$ : There is a statistically significant difference between the household income variable of Y-generation and the service quality determinants they perceive. 
$\mathbf{H}_{4}$ : The service quality determinants perceived by the Y-generation vary based on the travel companies.

\subsection{Populationand sample}

The research has been conducted to reveal the satisfaction constituents of Y-generation in terms of service quality determinants in travel services and examine these constituents in terms of demographic variables. The research population is Kurklareli University where the total number of students for the 2015-2016 academic year is 22.671 (http://oidb.klu.edu.tr/). For the populations with a size larger than 500.000 and above, a sample size of 384 is considered sufficient with 95\% trust (Kozak, 2014: 113). For the research, a questionnaire has been applied to 425 Y-generation tourism students studying in Kurklareli University Faculty of Tourism (normal and evening education).

\subsection{Datacollection instrument}

Questionnaire management was used as a data collection tool in the research. The measurement instrument used to measure the quality of service was developed from the research of Ardıç\&Sadaklıoğlu (2009) (39 items) and developed with the addition of new materials (21 items) in line with the information obtained from the literature.

As intentional sampling is the method preferred by the researcher that will help achieve the purposes within the research in the quickest and easiest way possible, this method has been applied for the research (Kozak, 2014: 118; Ural \&Kılıç, 2013: 42). 60 items aiming to reveal the quality of service components were included in the first past of the questionnaire, demographic variables were included in the second part. The statements measuring the service quality in the questionnaire are presented with five-point Likert scale ( $5=$ very pleased, 1= not pleased at all) (Churchill \&Iacobucci, 1999: 249). 425 of the 440 questionnaires distributed for the researchers were found to be healthy and the questionnaires including missing data have been excluded out of the analysis.

\subsection{The Limitation of the research}

- The fact that it is difficult to reach the population completely, due to restraints such as time, manpower and cost, poses a limitation in the research.

- The research is limited to the dates of May 15-June 10, 2016.

- The research is limited to the Y-generation youth studying in Kurklareli University Faculty of Tourism.

\subsection{Analysis of the Data}

The data analysis methods used in the research include the definitive statistics, Factor Analysis, T-Test and ANOVA Analysis. Loss data analysis has been conducted for the scale and it has been decided to fill in the missing values in the data set with the average. In addition, necessary extreme values have been checked. No extreme values with $Z$ value greater than +3 and lower than -3 have been encountered (Çokluk et al., 2010: 14). Skewness and Kurtosis values have been determined as $+1.5-1.5$. It procures the normality assumption according to Tabachnick and Fidell (2013) and Çokluk et al., (2010: 14).

\subsection{Demographicfindings}

\section{Interpretation of the analysis and findings}

$48.2 \%$ of the students participated in the questionnaire were female and $51.5 \%$ of the students were male, the most participated age bracket was observed as the age bracket $17-21$ with $56,7 \%$ and age bracket 22 26 with $40,7 \%$. It was found that $30.6 \%$ of the household income level of research participants had a household income of $2000 \mathrm{TL}$ and above. The company preferences of the respondents vary between two companies, Pamukkale Travel (42.1\%) and Metro Travel (40.5\%). 67.5\% of the participants stated that they traveled 0-3 times a week. Istanbul is the first ranked with a ratio of $47.3 \%$ in terms of family residence. When participants are satisfied with their travels, they prefer to share this with their friends/relatives (61.9\%).

\subsection{Factoranalysis}

For the research, the data collected from the $425 \mathrm{Y}$ generation representatives were evaluated with the help of the SPSS for Windows 22 statistical package program. First of all, in the analysis, the Principal Component Analysis was used to find factor structures belonging to a total of 60 items related to service quality determinants and Varimax was selected as the rotation method. Seven factors explaining 55.898\% of the total variance, which are above the load value of 40 and above the eigenvalues of 1 , are taken into consideration (Çokluk et al., 2010: 221). In the factor analysis, Comrey\& Lee (Nar. from 1992, Tabachnick\&Fidell, 2007) found that 50 is too weak, 100 is weak, 200 is medium, 300 is good, 500 is very good and 1000 is perfect. It is accepted that KMO value is 0,940 and sample size is suitable for factor analysis (Alpar, 2011: 286) and as a 
result of the Bartlett Sphericity test results the data $x^{2}=11943,413$, df $=1225$ came from normal distribution. (Şencan, 2005: 384).

The Cronbach Alpha value of 50 items, which were obtained as a result of the exclusion of the items under $40(35,28,5,51,56,8)$, determined to be the breakpoint in the Factor Analysis (Nar. from Comrey \& Lee, 1992, Tabachnick\& Fidel, 2007: 649) and composite items (46, 58, 39, 27) (Büyüköztürk, 2002a: 119), was found out as 0,956 and a total of 7 factor components have emerged. The reliability coefficient (Cronbach Alpha) takes a value between 0 and 1 , and as this value approaches 1 , the reliability increases (Ural \&Kıliç, 2013: 280). The Cronbach Alpha values of the following table factors are between 940 and 667. Alpar (2011: 815) noted that the Cronbach Alpha coefficient is high between 0,80-1,00, highly reliable between $0,60-0,79$, low between 0,40-0,59 and unreliable between 0,00-0,39. These factors include attitude and behavior of the personnel, physical qualities of buses, technology usage, ticket sale transactions and punctuality, supportive services, facilitating services and stopover components as seen in the table below. When the factor load values are examined, the load values of 0,60 and higher are high; the load values between 0.30-0.59 can be defined as moderate magnitudes (Büyüköztürk, 2002 ${ }_{\mathrm{b}}$ : 474). T-Test and ANOVA (One-Way ANOVA) Analysis were applied to investigate the differences in satisfaction levels in terms of service quality determinants of Ygeneration while travelling to demographic variables after reliability was provided.

Table 1: Factor analysis for the travel service quality assessment scale

\begin{tabular}{|c|c|c|c|c|}
\hline Factor Dimensions & $\begin{array}{l}\text { Factor } \\
\text { Loads }\end{array}$ & $\begin{array}{c}\text { Cronbach's } \\
\text { Alpha }\end{array}$ & $\begin{array}{l}\text { Explained } \\
\text { Variance }\end{array}$ & $\begin{array}{c}\text { Cumulative } \\
\text { Variance } \\
\text { ExplanationRatio }\end{array}$ \\
\hline $\begin{array}{l}\text { ATTITUDE AND BEHAVIOR OF THE } \\
\text { PERSONNEL }\end{array}$ & & 940 & 34,152 & \\
\hline From the respect of the personnel & ,804 & & & \\
\hline From the parlance of the personnel & ,799 & & & \\
\hline $\begin{array}{l}\text { From the personnel listening to you and trying to } \\
\text { understand }\end{array}$ & ,776 & & & \\
\hline From the personnel being patient and understanding & ,763 & & & \\
\hline From the behavior of the bus personnel against each other & ,718 & & & \\
\hline From the education and knowledge of the bus personnel & ,698 & & & \\
\hline $\begin{array}{l}\text { From the assessment of your complaints and efforts to } \\
\text { solve them }\end{array}$ & ,685 & & & \\
\hline From the hosts being attending to the passengers & ,658 & & & \\
\hline From the experience of the bus personnel & ,654 & & & \\
\hline From the hosts being good-humored & 645 & & & \\
\hline From the hosts' dialogue with passengers & ,631 & & & \\
\hline From the drivers' compliance to the traffic rules & ,568 & & & \\
\hline From the sincere behavior of the reservation officials & 560 & & & \\
\hline From the catering menu of the company & ,512 & & & \\
\hline From the service drivers being good-humored & ,497 & & & \\
\hline No errors in the receptions & ,457 & & & \\
\hline From the mobile phones of the drivers being open & ,443 & & & \\
\hline From providing an explanation in the event of a trouble & ,438 & & & \\
\hline From the cleanliness of the waiting halls &, 412 & & & \\
\hline PHYSICAL QUALITIES OF THE BUS & & ,887 & 5,283 & 39,436 \\
\hline From the buses being clean & ,701 & & & \\
\hline From the buses being new & ,679 & & & \\
\hline From the buses' ventilation systems being operational & ,663 & & & \\
\hline From the external appearance of the buses & 657 & & & \\
\hline From the internal appearance of the buses & ,656 & & & \\
\hline From announcement made in the bus being explanatory & ,478 & & & \\
\hline From providing luggage vouches for commodities & ,476 & & & \\
\hline TECHNOLOGY USAGE & & ,835 & 4,062 & 43,497 \\
\hline From the availability of a website, social media pages & ,708 & & & \\
\hline From closely monitoring the technological developments & ,681 & & & \\
\hline From Wi-Fi service & ,675 & & & \\
\hline $\begin{array}{l}\text { From the travel company being easily accessible via } \\
\text { website and phone }\end{array}$ & ,614 & & & \\
\hline $\begin{array}{l}\text { From the presentation of updated movies, music and TV } \\
\text { broadcast }\end{array}$ & ,587 & & & \\
\hline From the vehicles including sockets & ,499 & & & \\
\hline $\begin{array}{l}\text { TICKET SALE TRANSACTIONS AND } \\
\text { PUNCTUALITY }\end{array}$ & &, 780 & 3,460 & 46,958 \\
\hline From the number of ticket sale offices being sufficient & ,734 & & & \\
\hline From the ticket sale office being easily accessible & ,682 & & & \\
\hline
\end{tabular}


Service quality determinants in highway travel services a research on Y-generation

\begin{tabular}{|l|r|r|l|l|}
\hline From the communication among the ticket sale offices &, 670 & & & \\
\hline From the bus hours being convenient &, 515 & & & \\
\hline $\begin{array}{l}\text { From the availability of service to the places required by } \\
\text { the customer }\end{array}$ &, 499 & & & \\
\hline From the buses departing on time &, 423 & & & \\
\hline From the buses arriving on time &, 411 & & & \\
\hline SUPPORTIVE SERVICES &, 698 & & & \\
\hline From sitting on the window side &, 692 & & & \\
\hline From the application of single seats &, 552 & & & \\
\hline From having a scheduled trip to my city &, 507 & & & \\
\hline From the services being provided as committed & &, 731 & 2,930 & \\
\hline FACILITATING SERVICES &, 776 & & & \\
\hline $\begin{array}{l}\text { From having technical equipment for handicapped } \\
\text { citizens }\end{array}$ &, 713 & & & \\
\hline From the vehicles having toilets &, 616 & & & \\
\hline From being remembered on special days (birthday, etc.) &, 573 & & & \\
\hline From the companies being environment-friendly &, 795 & & & \\
\hline STOPOVER &, 785 & & & \\
\hline From the number of stopovers being sufficient &, 441 & & & \\
\hline The stopover periods being convenient & & & \\
\hline $\begin{array}{l}\text { From the services being provided at accommodation } \\
\text { places }\end{array}$ & & & \\
\hline
\end{tabular}

$*\left(\mathrm{~N}=425 ;\right.$ Varimax Rotated Principal Components Factor Analysis; KMO= 0,940; $<<, 000 ; \mathrm{x}^{2}=11943,413$, $\mathrm{df}=1225)$.

Factor 1: Attitude and Behavior of the Personnel which explains the highest variance as a result of the factor analysis with 34,152\%, is constituted with the combination of 19 items. Factor 2: Physical Qualities of the Bus constitutes 5,283\% of the variance; Factor 3: Technology usage constitutes $4.062 \%$ of the variance; Factor 4: Ticket Sale Transactions and Punctuality constitutes 3,460\% of the variance; Factor 5: Supportive Services constitutes $4.062 \%$ of the variance; Factor 6: Facilitating Services constitutes 2,919\% of the variance and Factor 7: Stopover constitutes 2,692\% of the variance

\subsection{Analysis of the travel service quality components in terms of demographic variables}

The level of service quality that the Y-generation perceive when traveling on the basis of gender variable was analyzed by t-test. The level of service quality that they perceive according to age, household income and company variables were tested by ANOVA analysis. Assumptions for normality and equality of variance, which are required for ANOVA analysis, were provided. The Tukey test was applied to the Post Hoc tests to find out which group create the differences in the study.

Table 2:T- Test analysis in terms of the service quality components based on gender variable

\begin{tabular}{|c|c|c|c|c|c|c|c|}
\hline FACTORS & Gender & $\mathrm{N}$ & Avg. & $\begin{array}{c}\text { Std. } \\
\text { Deviation }\end{array}$ & $\bar{F}$ & $\mathrm{p}$ & difference \\
\hline \multirow{2}{*}{$\begin{array}{l}\text { ATTITUDE AND } \\
\text { BEHAVIOUR OF } \\
\text { PERSONNEL }\end{array}$} & Female & 205 & 3,3761 & ,83232 & ,025 & ,874 & \\
\hline & Male & 220 & 3,5082 &, 81280 & & & \\
\hline \multirow{2}{*}{$\begin{array}{l}\text { PHYSICAL QUALITIES OF } \\
\text { THE BUS }\end{array}$} & Female & 205 & 3,6270 & ,89326 & ,199 & ,656 & \\
\hline & Male & 220 & 3,7004 & ,87763 & & & \\
\hline \multirow{2}{*}{$\begin{array}{l}\text { TECHNOLOGY } \\
\text { USAGE }\end{array}$} & Female & 205 & 3,2199 & 99269 &, 402 &, 527 & \\
\hline & Male & 220 & 3,2381 & 98343, & & & \\
\hline \multirow{2}{*}{$\begin{array}{l}\text { TICKET SALE } \\
\text { TRANSACTIONS AND } \\
\text { PUNCTUALITY }\end{array}$} & Female & 205 & 3,6585 & ,74037 & 2,047 & ,153 & \\
\hline & Male & 220 & 3,6230 & ,81226 & & & \\
\hline \multirow[t]{2}{*}{ SUPPORTIVE SERVICES } & Female & 205 & 4,0991 & 82275 & ,129 & ,719 & \\
\hline & Male & 220 & 4,0307 & 81032 & & & \\
\hline \multirow{2}{*}{$\begin{array}{l}\text { FACILITATING } \\
\text { SERVICES }\end{array}$} & Female & 205 & 2,8439 & 1,03759 & 2,467 & ,117 & \\
\hline & Male & 220 & 3,0315 & 1,12777 & & & \\
\hline \multirow[t]{2}{*}{ STOPOVER } & Female & 205 & 3,3606 & 86683 & 5,008 & ,026* & $1-2$ \\
\hline & Male & 220 & 3,4073 & ,98288 & & & \\
\hline
\end{tabular}

(95\% significance level)

In terms of travel service quality determinants, a significant difference exists only for the Turnover variable based on the gender variable among Y-generation $(p<0,05)$. During the travels, male passengers of $Y$ - 
generation $(x=3,4073)$ have higher satisfaction levels compared to female passengers of Y-generation ( $\mathrm{x}=3,3606)$. According to these results, $\mathrm{H}_{1}$ hypothesis is accepted only for stopover variable. In terms of travel service quality determinants, no significant differences exist for the household income variables based on the gender variable among Y-generation $(\mathrm{p}<0,05)$. Therefore, $\mathrm{H}_{2}$ and $\mathrm{H}_{3}$ hypotheses were rejected.

Table 3: ANOVA analysis regarding the service quality determinants based on travel companies

\begin{tabular}{|c|c|c|c|c|c|c|c|}
\hline & & $\mathrm{n}$ & $\begin{array}{l}\text { Avg. } \\
\text { (x) }\end{array}$ & S.S. & $\mathrm{F}$ & $\mathrm{P}$ & $\begin{array}{c}\text { TUKEY } \\
\text { Test Results }\end{array}$ \\
\hline \multirow{7}{*}{$\begin{array}{l}\text { ATTITUDE AND } \\
\text { BEHAVIOUR OF } \\
\text { PERSONNEL }\end{array}$} & $\begin{array}{l}\text { (1)PAMUKKAL } \\
\text { E }\end{array}$ & 179 & 3,7998 & 66683 & & & \\
\hline & (2) METRO & 172 & 3,1203 & ,84971 & & & \\
\hline & (3)NILUFER & 20 & 3,2141 & ,93573 & 15,789 & ,000 & $1,3,2-5$ \\
\hline & $\begin{array}{l}\text { (4)ISTANBUL } \\
\text { SEYAHAT }\end{array}$ & 9 & 3,4060 & ,73517 & & & \\
\hline & $\begin{array}{l}\text { (5)OTHER } \\
\text { COMPANIES }\end{array}$ & 29 & 3,5937 & 66928 & & & \\
\hline & Lost data & 16 & 2,9943 & 63798 & & & \\
\hline & Total & 425 & 3,4445 & 82396 & & & \\
\hline \multirow{7}{*}{$\begin{array}{l}\text { PHYSICAL } \\
\text { CHARACTERISTICS } \\
\text { OF THE BUS }\end{array}$} & $\begin{array}{l}\text { (1)PAMUKKAL } \\
\text { E }\end{array}$ & 179 & 3,9470 &, 78790 & & & \\
\hline & (2)METRO & 172 & 3,4090 & ,92475 & & & \\
\hline & (3)NILUFER & 20 & 3,5791 & ,77651 & & & \\
\hline & $\begin{array}{l}\text { (4)ISTANBUL } \\
\text { SEYAHAT }\end{array}$ & 9 & 3,7619 & ,65075 & 7,579 & ,000 & 1,2 \\
\hline & $\begin{array}{l}\text { (5)OTHER } \\
\text { COMPANIES } \\
\end{array}$ & 29 & 3,6559 & ,84049 & & & \\
\hline & Lost data & 16 & 3,3304 & ,93564 & & & \\
\hline & Total & 425 & 3,6650 & ,88492 & & & \\
\hline \multirow[t]{7}{*}{$\begin{array}{l}\text { TECHNOLOGY } \\
\text { USAGE }\end{array}$} & $\begin{array}{l}\text { (1)PAMUKKAL } \\
\text { E }\end{array}$ & 179 & 3,6618 & ,81734 & & & \\
\hline & (2) METRO & 172 & 2,8227 & ,96147 & 15,176 &, 000 & $1,2,5$ \\
\hline & (3)NILUFER & 20 & 3,1833 & ,96412 & & & \\
\hline & $\begin{array}{l}\text { (4)ISTANBUL } \\
\text { SEYAHAT }\end{array}$ & 9 & 3,2593 & ,91709 & & & \\
\hline & $\begin{array}{l}\text { (5)OTHER } \\
\text { COMPANIES }\end{array}$ & 29 & 3,1379 & ,98608 & & & \\
\hline & Lost data & 16 & 2,9687 & 1,18199 & & & \\
\hline & Total & 425 & 3,2293 & ,98678 & & & \\
\hline \multirow{7}{*}{$\begin{array}{l}\text { TICKET } \\
\text { SALE } \\
\text { TRANSACTIONS AND } \\
\text { PUNCTUALITY }\end{array}$} & $\begin{array}{l}\text { (1)PAMUKKAL } \\
\text { E }\end{array}$ & 179 & 3,7891 & ,75942 & & & \\
\hline & (2) METRO & 172 & 3,5029 & ,80407 & & & \\
\hline & (3)NILUFER & 20 & 3,4801 & ,64060 & 3,862 & ,002 & 1,2 \\
\hline & $\begin{array}{l}\text { (4)ISTANBUL } \\
\text { SEYAHAT }\end{array}$ & 9 & 3,5658 & ,65852 & & & \\
\hline & $\begin{array}{l}\text { (5)OTHER } \\
\text { COMPANIES } \\
\end{array}$ & 29 & 3,8655 & ,69515 & & & \\
\hline & Lost data & 16 & 3,2824 & ,68993 & & & \\
\hline & Total & 425 & 3,6401 & ,77770 & & & \\
\hline \multirow[t]{7}{*}{$\begin{array}{l}\text { SUPPORTIVE } \\
\text { SERVICES }\end{array}$} & $\begin{array}{l}\text { (1)PAMUKKAL } \\
\text { E }\end{array}$ & 179 & 4,2412 & ,74258 & & & \\
\hline & (2) METRO & 172 & 3,9405 & ,85543 & & & \\
\hline & (3)NILUFER & 20 & 3,7625 & ,86021 & & & \\
\hline & $\begin{array}{l}\text { (4)ISTANBUL } \\
\text { SEYAHAT }\end{array}$ & 9 & 4,0000 & ,84779 & 3,344 & ,006 & 1,2 \\
\hline & $\begin{array}{l}\text { (5)OTHER } \\
\text { COMPANIES }\end{array}$ & 29 & 4,0440 & ,77236 & & & \\
\hline & Lost data & 16 & 3,8502 & ,88523 & & & \\
\hline & Total & 425 & 4,0637 & ,81609 & & & \\
\hline \multirow[t]{7}{*}{$\begin{array}{l}\text { FACILITATIVE } \\
\text { SERVICES }\end{array}$} & $\begin{array}{l}\text { (1)PAMUKKAL } \\
\text { E }\end{array}$ & 179 & 3,1824 & 1,02332 & & & \\
\hline & (2) METRO & 172 & 2,6807 & 1,15112 & & & \\
\hline & $\begin{array}{l}\text { (3)NILUFER } \\
\end{array}$ & 20 & 2,8456 & 1,09755 & & & \\
\hline & $\begin{array}{l}\text { (4)ISTANBUL } \\
\text { SEYAHAT }\end{array}$ & 9 & 3,1619 & ,80164 & 3,989 & ,002 & 1,2 \\
\hline & $\begin{array}{l}\text { (5)OTHER } \\
\text { COMPANIES }\end{array}$ & 29 & 2,9512 & ,97323 & & & \\
\hline & Lost data & 16 & 3,0156 & ,87782 & & & \\
\hline & Total & 425 & 2,9410 & 1,08799 & & & \\
\hline STOPOVER & (1)PAMUKKAL & 179 & 3,6097 & ,88362 & & & \\
\hline
\end{tabular}


Service quality determinants in highway travel services a research on Y-generation

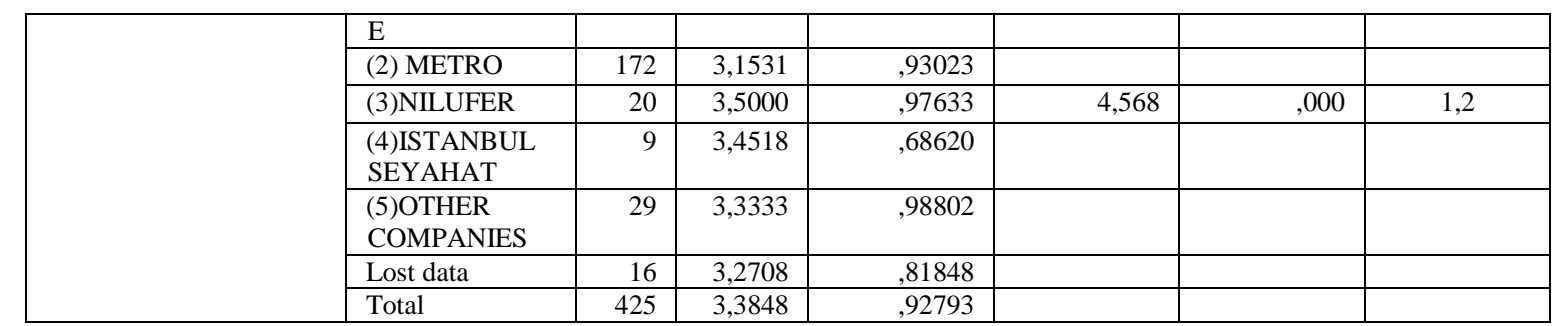

(95\% significance level)

The table above represent a statistically significant difference between the travel satisfaction variables and companies.According to these results, the Y-generation youth preferring to travel with the Pamukkale Company $(\mathrm{x}=3,7998)$ are more satisfied from the Attitude and Behavior of the Personnel compared to Metro $(x=3,1203)$ and NilüferCompanies $(x=3,2141)$ and those traveling with Nilüfer Company $(x=3,2141)$ are more satisfied from the Attitude and Behavior of the Personnel compared to Metro Company $(x=3,1203)$. The satisfaction levels of Y-generation from Pamukkale Company compared in terms of physical qualities of the Bus $(\mathrm{x}=3,9470)$ are higher compared to Metro Company $(\mathrm{x}=3,4090)$. The satisfaction levels of $\mathrm{Y}$-generation from Pamukkale Company compared in terms of Technology Usage of the Bus $(x=3,6618)$ are higher compared to Metro Company ( $\mathrm{x}=2,8227)$. Y-generation's satisfaction perception is higher from Pamukkale Company $(x=3,7891)$ compared to Metro Company $(x=3,5029)$ in terms of Ticket Sale Transactions and Punctuality; higher from Pamukkale Company $(x=4,2412)$ compared to Metro Company $(x=3,9405)$ in terms of Supportive Services; higher from Pamukkale Company $(x=3,1824)$ compared to Metro Company $(x=$ $2,6807)$ in terms of Facilitative Services and higher from Pamukkale Company $(x=3,6097)$ compared to Metro Company ( $\mathrm{x}=3,1531)$ in terms of Stopovers. According to these results, $H_{4}$ hypothesis is accepted.

\section{Conclusionsand suggestions}

Due to the intense competition in road travel, which makes the tourism sector active every year and contributes significantly to the tourist movements in our country, it has become important for the competition to differentiate from tourists and to provide better quality services to their passengers.Thus, efforts have been made to investigate the determinants of service quality in road travels of Y-generation, the travelers of the future, which are expressed as the Millennium generation in the study, and these determinants in terms of demographic variables. According to the results obtained from this research, the quality of service determinants of Y-generation travels consists of attitude and behavior of the personnel, physical qualities of buses, technology usage, ticket sale transactions and punctuality, supportive services, facilitating services and stopover. As a result of the research, "Attitude and Behavior of the Personnel" appeared as the most important factor dimension. The results of this research are similar to those of other studies in the literature on the importance of personnel behavior among the determinants of travel service quality (Koçoğlu\&Aksoy, 2012; Ardıç\&Sadaklıŏlu, 2009; Duman et al., 2007; Altan\&Engin, 2004; Edvardsson, 1998). On the other hand, according to the service quality components of travel, it is observed that no significant difference in terms of age and household income variables of Y-generation has emerged. According to the research results of Yilmaz (2012: 80), the averages for the dimensions of students' perceptions of quality of urban bus services do not differ significantly according to their gender, age and education. The results of this research are in line with the results of Yilmaz (2012) in terms of age variable. One of the other results of the research is that the level of satisfaction among male passengers is higher than female passengers in terms of time change. In the study by Duman et al. (2007: 157), it was found that stopover places were not a direct determinant of the loyalty of the customers, being one of the factors determining the quality perception of the service received by the customer. Finally, it was found out that the satisfaction level of the Y-generation, which preferred PamukkaleCompany was higher than the other firms, is higher in terms of the attitude and behavior of the personnel, physical qualities of the bus, technology usage, ticket sale transactions and punctuality, supportive services, facilitative services and stopovers.

- As a result, company owners should attach importance to their training in terms of physical evidence such as attitude and behavior of the personnel, courtesy, body language, mimics, and being good-humored and should carry out training meetings for certain periods within this scope.

- In order to increase the professional knowledge of personnel, on-the-job/off-the-job training should be provided by the company managers and the training should be adapted to the requirements of the age.

- Companies should provide entertaining and appealing advertisements that may attract the young generation and social networks should be utilized in this respect.

- Considering the technology that is indispensable in the life of Y-generation, Wi-Fi and charge socket services should absolutely be available in the bus. 
- Updated movies, music and TV broadcasts that will help the Y-generation a more entertained time during their travels should not be forgotten.

Future research can examine the job satisfaction and the effects of job satisfaction on the operational efficiency of personnel working in road travel enterprises. In addition to Y-generation, a few years later, travel perceptions of the Z-generation that will be actively involved in road, air etc. travels can be evaluated.

\section{References}

[1]. Adıgüzel, O.; Batur, H.Z. \& Ekşili, N. (2014). Kuşakların değişen yüzü ve Y kuşağı ile ortaya çıkan yeni çalışma tarzı: mobil yakalılar. Süleyman Demirel Üniversitesi Sosyal Bilimler Enstitüsü Dergisi, Y11: 2014/1, Say1:19, 165182.

[2]. Albayrak, A. \& Özkul, E. (2013). Y kuşağı turistlerin destinasyon imaj algıları üzerine bir araştırma. Turkish Studies, 8 (6), 15-31.

[3]. Alpar, R. (2011). Uygulamalı çok değişkenli istatistiksel yöntemler (3. baskı). Ankara: Detay.

[4]. Altan, M. \& Engin, O. (2004). Bir seyahat işletmesinin müşteri memnuniyetinin ölçülmesi. Selçuk Üniversitesi Sosyal Bilimler Enstitüsü Dergisi, 11, 585-598.

[5]. Altuntuğ, N. (2012). Kuşaktan kuşağa tüketim olgusu ve geleceğin tüketici profili. Organizasyon ve Yönetim Bilimleri Dergisi, 4 (1), 203-212.

[6]. Ardıç, K \& Sadaklığlu H. (2009). Şehirlerarası yolcu taşımacılığında hizmet kalitesinin ölçümü: Tokat örneği. Atatürk Üniversitesi İktisadi ve İdari Bilimler Dergisi, 23 (3), 167-190.

[7]. Bayhan, V. (2014). Milenyum veya (Y) kuşağı gençliğin sosyolojik bağlamı. Gençlik Araştırmaları Dergisi, 2 (3), 2014-1, 8-25.

[8]. Brady, M. K. \& Cronin Jr., J. J. (2001). Some new thoughts on conceptualizing perceived service quality: a hierarchical approach. The Journal of Marketing, 65 (3), (Jul., 2001), pp. 34-49.

[9]. Büyüköztürk, Ş. (2002 $)$. Sosyal bilimler için veri analizi el kitabı: istatistik, araştırma deseni, SPSS uygulamaları ve yorum (birinci bask1). Ankara: Pegem A.

[10]. Büyüköztürk, Ş. $\left(2002_{\mathrm{b}}\right)$. Faktör analizi: temel kavramlar ve ölçek geliştirmede kullanımı. Kuram ve Uygulamada Ĕ̈itim Yönetimi, 32, 470-483.

[11]. Chen, C. \& Chen, F. (2010). Experience quality, perceived value, satisfaction and behavioral intentions for heritage tourists. Tourism Management, 31 (2010), 29-35.

[12]. Churchill, G. A. \& Iacobucci, D. (1999). Marketing research: methodological foundations (tenth edition). USA: South-Western Cengage Learning.

[13]. Çemberci, M.; Sudak, M. K.; Aşçı, S.; Öz, S. \& Civelek, M. E. (2014). Y neslinin örgüt ortamındaki davranış farklılıklarının analizi. Online Academic Journal of Information Technology, 5 (15), 57-74, DOI:10.5824/1309-- 1581.2014.2.004.x.

[14]. Çokluk, Ö.; Şekercioğlu, G. \& Büyüköztürk, Ş. (2010). Sosyal bilimler için çok değişkenli istatistik-SPSS ve LISREL Uygulamaları. Ankara: Pegem Akedemi.

[15]. Duman, T; Ayduğan, P. \& Koçak, G.N. (2007). Karayolu yolcu taşımacıllğ̆ hizmetlerinde hizmet kalitesi, hizmet değeri, müşteri memnuniyeti ve müşteri sadakati ilişkileri. Dokuz Eylül Üniversitesi Sosyal Bilimler Enstitüsü Dergisi, 9 (1), 151-177.

[16]. Edvardsson, B. (1998). Causes of customer dissatisfaction-studies of public transport by the critical-incident method. Managing Service Quality, 8, (3), 189-197.

[17]. Franzidis, A. \& Hritz, N. (2014). Profiling the gen Y tourist. Tourism Research Notes, 62 (3), 323,330.

[18]. Godfrey, K. \& Clarke, J. (2000). The tourism development handbook-A practical approach planning and marketing. UK: Thomson.

[19]. Goeldner,C. R. \& Ritchie, J.R.(2012). Tourism principles, practices, philosophy. Canada: John Wiley \& Sons.

[20]. Gurski, D. (2014). Customer experiences affect customer loyalty: an empirical investigation of the starbucks experience using structural equation modeling. Hamburg: Anchor Academic Publishing.

[21]. Horner, S. \& Swarbrooke, J. (2005). Leisure marketing, a global perspective. Great Britain: Elsevier.

[22]. İçöz, O. (2000). Seyahat acentaları ve tur operatörlüğ̈̈̈ yönetimi. Ankara: Turhan.

[23]. Kattiyapornpong, U. (2009). Profiling generation Y - where do they travel?. Proceedings of the Australian and New Zealand Marketing Academy Conference, ANZMAC (pp. 1-7). Melbourne, Victoria: Monash University.

[24]. Koçoğlu, C. M. \& Aksoy, R. (2012). Hizmet kalitesinin SERVPERF yöntemi ile ölçülmesi: otobüs işletmeleri üzerine bir uygulama. Akademik Bakış Dergisi, 29 (Mart-Nisan 2012), 1-20.

[25]. Kozak, M. (2014). Bilimsel araştırma: tasarım, yazım ve yayım teknikleri. Ankara: Detay.

[26]. Kozak, N; Kozak, M.A.ve Kozak, M. (2014). Genel Turizm İlkeler Kavramlar (16.Bask1). Ankara: Detay.

[27]. Latif, H. \& Serbest, S. (2014). Türkiye'de 2000 kuşağı ve 2000 kuşağının iş ve çalışma anlayışı. Gençlik Araştırmaları Dergisi, 2 (4), 2014-4, 132-163.

[28]. Middleton, V.T.C.; Fyall, A.; Morgan, M. \& Ranchhod, A. (2009). Marketing in travel and tourism. UK: Butterworth-Heeinemann.

[29]. Özgüven, N. (2008). Hizmet pazarlamasında müşteri memnuniyeti ve ulaştırma sektörü üzerine bir uygulama. Ege Akademik Bakış, 8 (2), 651-682.

[30]. Öztürk, S. A. (2010). Hizmet Pazarlaması: Kuram Uygulama ve Örnekler (10. Baskı). Bursa: Ekin.

[31]. Parasuraman, A. A.,Zeithaml, V. A., \& Berry, L. L. (1988). SERVQUAL: A multiple-item scale for measuring consumer perceptions of service quality. Journal of Retailing, 64 (1), 12-40. 
[32]. Parasuraman, A., Zeithaml, V. A., \& Berry, L. L. (1994). Alternative scales for measuring service quality: a comparative assessment based on psychometric and diagnostic criteria. Journal of Retailing, 70 (3), 201-230.

[33]. Seçilmiş, C. \& Köz, E. N. (2015). Sürdürülebilir kültür turizmi algısının nesillere göre tekrar gelme niyetine etkisi. Journal of Tourism and Gastronomy Studies,3 (3), 69-78.

[34]. SSencan, H. (2005). Sosyal ve davranışsal ölçümlerde güvenilirlik ve geçerlilik (birinci baskı). Ankara: Seçkin.

[35]. Tabachnick, B. \& Fidell, L.S. (2007). Using multivariate statistics (5th ed.). Boston: Ally \& Bacon.

[36]. Ural, A. \& Kilıç., İ. (2013). Bilimsel araştırma süreci ve SPSS ile veri analizi. Ankara: Detay.

[37]. Urban, W. (2010). Customers' experiences as a factor affecting perceived service quality. Economics and Management, $8(1), 820-826$.

[38]. Wu, S.; Huang, C. \& Chen, Y.(2015) Leisure-service quality and hedonic experiences: singing at a karaoke house as a form of theatre, total quality. Management \& Business Excellence, 26 (3-4), 298-311.

[39]. Yılmaz, İ. (2012). Turizm öğrencilerinin karayolu yolcu taşımacılığı hizmetlerine yönelik algılamaları. Anatolia: Turizm Araştırmaları Dergisi, 23 (1), 73-85.

[40]. Yüksekbilgili, Z. (2013). Türk tipi Y kuşağı. Elektronik Sosyal Bilimler Dergisi, 12 (45), 342-353.

[41]. Zengin, B. \& Şen, L. M. (2015). Seyahat işletmeleri (in Turizm İşletmeleri-3. Bask1, Ed. Burhanettin Zengin ve Şehnaz Demirkol), İstanbul: Değişim.

\section{E- References}

[42]. https://d2bxpc4ajzxry0.cloudfront.net/TripAdvisorInsights/sites/default/files/downloads/2670/globalreport_turkish_d ec2015.pdf, the date of access; 27/09/2016.

[43]. http://www.ubak.gov.tr/BLSM_WIYS/UBAK/tr/doc-xls/20120726_162224_204_1_64.pdf, the date of access; $11 / 10 / 2016$.

[44]. http://www.tuik.gov.tr/PreTablo.do?alt_id=1051, the date of access; 13/12/2016.

[45]. http://oidb.klu.edu.tr/Yardimci_Sayfalar/456-2015-2016-egitim-ogretim-yili-ogrenci-sayilari.klu, the date of access; 21/11/2016. 